\title{
Mount Kakoulima: An Overview and Analysis
}

\author{
Ahmed Amara Konaté ${ }^{1,2}$ \& Heping Pan ${ }^{1}$ \\ ${ }^{1}$ Institute of Geophysics and Geomantic, China University of Geosciences, Wuhan, China \\ ${ }^{2}$ Institut Supérieur des Mines et Géologie de Boké, Guinea \\ Correspondence: Ahmed Amara Konaté, Institute of Geophysics and Geomantic, China University of \\ Geosciences, Wuhan, China. E-mail: konate77@yahoo.fr
}

Received: December 26, 2012 Accepted: January 31, 2013 Online Published: February 20, 2013

doi:10.5539/esr.v2n2p23 URL: http://dx.doi.org/10.5539/esr.v2n2p23

\begin{abstract}
The interest generated by mafic-ultramafic rocks is justified by the fact that their structure and formational processes not only have scientific importance but also can lead to metal concentrations, making them economically viable. Located $50 \mathrm{~km}$ north-east of Conakry, Guinea's capital, Mount Kakoulima has long been one of the mafic-ultramafic rock areas of the world but has yet to be exploited; thus limited data have been published concerning it. The goal of this investigation is to describe the structure and formation process of Mount Kakoulima by means of geological field observations. The findings indicate that Mount Kakoulima is a stratified solid rock, formed with the result of some magma injections in some intrusive phases. With a Lithological sequence progressing from peridotite (dunite) to pyroxenite to extensive gabbro. The result will improve the understanding of geological processes on Mount Kakoulima to guide future surveys on mineral ores in the scientific and academic community for research and studies in the field of earth sciences.
\end{abstract}

Keywords: Mount Kakoulima, intrusive complex, mafic-ultramafic, Guinea

\section{Introduction}

Located $50 \mathrm{~km}$ north-east of the capital of Republic of Guinea (Conakry), Kakoulima Complex (Latitude: 9.76694, Longitude: -13.445 and Altitude: $1011 \mathrm{~m}$ ) dominates the vast plain of lower Guinea. A large part of its slopes is covered by secondary growth vegetations. Frequent fogs, periodic edaphic drought and atmospheric humidity are the essential factors that dominate the ecology of these ridges (Schnell, 1950).

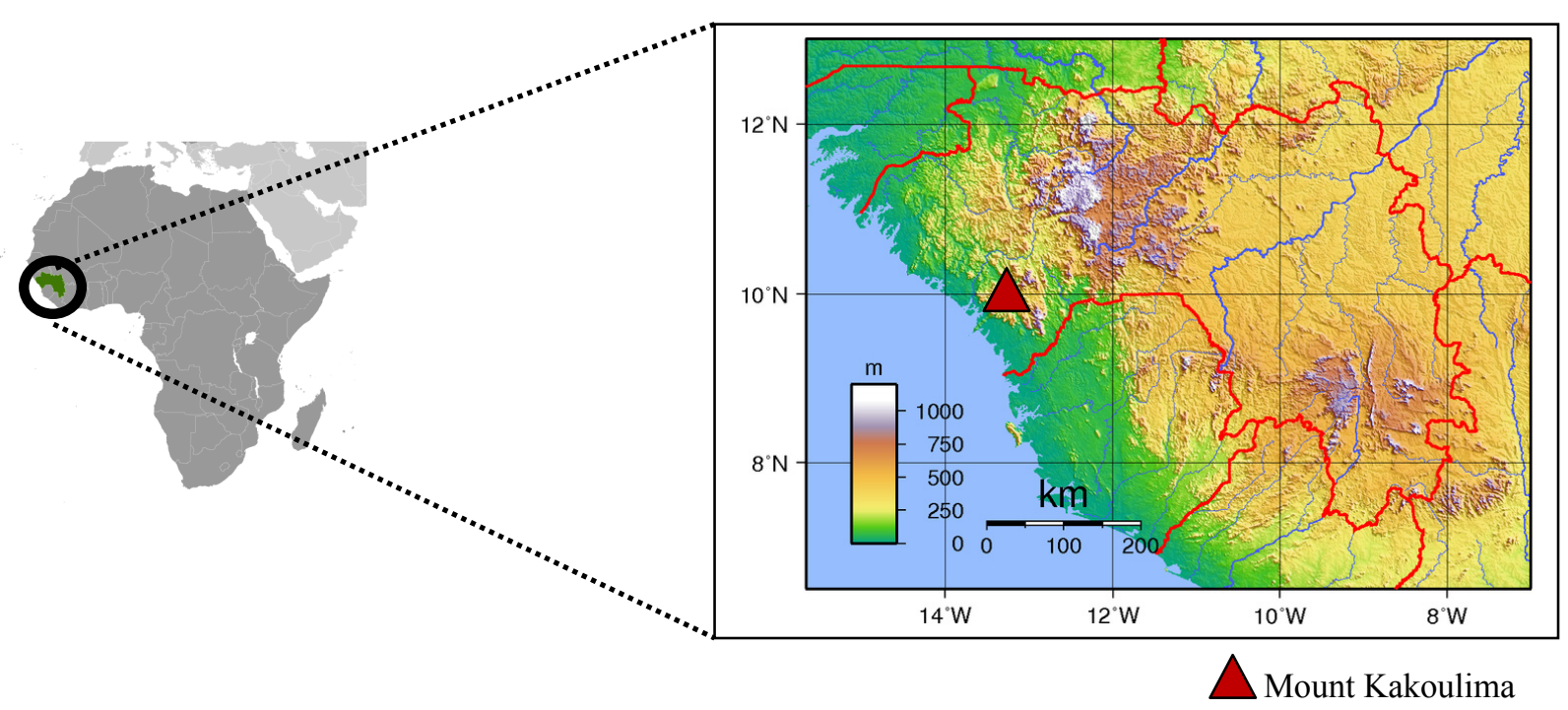

Figure 1. Map of Africa highlighting Guinea

Source: http://www.eoearth.org/
Figure 2. Map of Guinea highlighting the location of Mt Kakoulima

Source: http://www.eoearth.org/ 
The importance in mafic-ultramafic rocks is proven by the fact their study in their various associations leads to two essential problems: the original and current constitution globe, and the genesis and differentiation of magma. In addition, the structure and formational process of mafic-ultramafic rocks may lead to metal concentrations which give them a great economic interest. This was related by several authors in their studies, such as Moores (1973); Gebauer et al. (1981); Wilson (1982); Naldrett (1989); Ferrsrio et al. (1990); Sun et al. (1991); Quadt (1992); Barnes (1994); Gebauer (1996); Garuti et al. (1997); Puchtel et al. (1999); Okano et al. (2000); Dean (2002); Schoenberg et al. (2003); Cawthorn and McKenna (2006); Pirajno et al. (2008); Cawthorn and Lewis (2009).

Virtually most of the world class nickel-Platinum Group Element is produced from mafic-ultramafic complexes. The deposits containing iron, nickel, copper, and Platinum Group Elements (PGE) occur as sulphide concentrations associated with a variety of mafic and ultramafic rocks (Eckstrand et al., 2004; Naldrett, 2004).

In Guinea, these rocks constitute the base of the Peninsula of Kaloum (Kaloum Igneous Complex [KIC]) and are stretched towards the continent where they form the solid mass of Mount Kakoulima (Sylla, 1995). The drilling wells AF0007 to AF0012 which were executed and analyzed by Mega uranium (2004) on the North Grid of the Mount Kakoulima had successfully proven in confirming the original theory that the base of the KIC dips to the south along its northern contact. It dips roughly around $45^{\circ}$ inward, and had the capacity to provide traps for concentrating sulphides. The rock types supported in the KIC are consistent with other mineralized mafic-ultramafic intrusions and the contamination of KIC by gneissic wall rocks is a positive feature.

Mount Kakoulima (hereafter referred to as $M K$ ), one of the world's mafic-ultramafic areas for an extended period of time has yet to be exploited in this context. Chromite and massive sulphides are known in thin subhorizontal horizons near the base of MK (Sable Mining, 2010). Exceptionally, due to favorable natural conditions (high rainfall, high humidity even in the dry season), MK is encircled by dense, picturesque vegetation and controls the rainfall in the Kaloum peninsula.

From the point of view of structure, there are possible analogues of styles among the Great Dyke in Zimbabwe, the Bushveld Igneous Complex in South Africa, and the Stillwater Igneous Complex in Montana (USA). Furthermore, Mega Uranium Ltd. via Marketwire News Releases (2006) confirmed that "there is the potential for massive sulphides similar to the Jinchuan nickel-copper deposit in China".

Due to inadequate resources and support for local research teams, little scientific investigations on MK were realized. Despite these setbacks, Lacroix (1905) described the Central Atlantic Magmatic Province (CAMP) in Guinea, Diallo et al. (1992) discussed the relations with the doleritic sills of Western Guinea and the Central Atlantic rifting, Deckart et al. (2005) studied Geochemistry and $\mathrm{Sr}, \mathrm{Nd}, \mathrm{Pb}$ isotopic composition of the CAMP in Guyana and Guinea, and some Mining Companies recognized iron, nickel, copper, cobalt, chrome and PGE mineralizations on MK.

The scope of this paper will help contribute to an understanding of the structure and formational process of MK. The investigative methods involved geological field observations. The findings will improve the understanding of geological processes on the intrusive complex as a guide to further surveys on metals and minerals. Also, this article presents the current state of knowledge on the geological and structural complex intrusive of MK that will be accessible to the scientific and academic community interested in the field of earth sciences. It is hoped that this paper will encourage further studies and research on the issue.

\section{Geological Basement}

The majority of basement in West Africa was formed during three major orogenic events, these are (as cited by Deckart et al., 2005): Liberian ( 2.7 Ga, Hurley et al., 1971), Eburnian ( 2.1 Ga=Trans-Amazonian) affecting the Birimian terrains (Abouchami et al., 1990; Ligéois et al., 1991; Boher et al., 1992) and Pan-African (mainly 750-660 and 650-580 Ma; Liégeois et al., 1994). The oldest rocks of Guinea belong to the south-western edge of the West African craton - the Kenema-Man Shield (Archean to Palaeoproterozoic) shared between Guinea, Sierra Leone, Liberia and Ivory Coast, and adjacent Pan-African belts of Rockelides and Bassarides, which are thrust upon the craton and partly covered by the Palaeozoic Bove Basin (Deckart et al., 2005; Villeneuve \& Corné, 1994).

The Archean core is characterized by gneisses, granite-gneiss, granites and then by typical association granites-greenstone which are affected by various orogenic of which the last, Liberian orogeny, (2.75 billion years) rejuvenated the existing craton with a very advanced metamorphism having like results, the installation of the large granitoid solid masses (Brinckmann et al., 2008) and offering an environment that may have been suitable for the formation of massive sulphide deposits. In other words, the gites are commonly found in Archean 
cratons stable. These Archean cratons are privileged establishment of large stratiform complexes such as MK. The single biotite grains from intrusive formation from the Kakoulima area yielded plateau age of $200.4 \pm 0.2$ Ma (Deckart et al., 1997; Nomade et al., 2007).

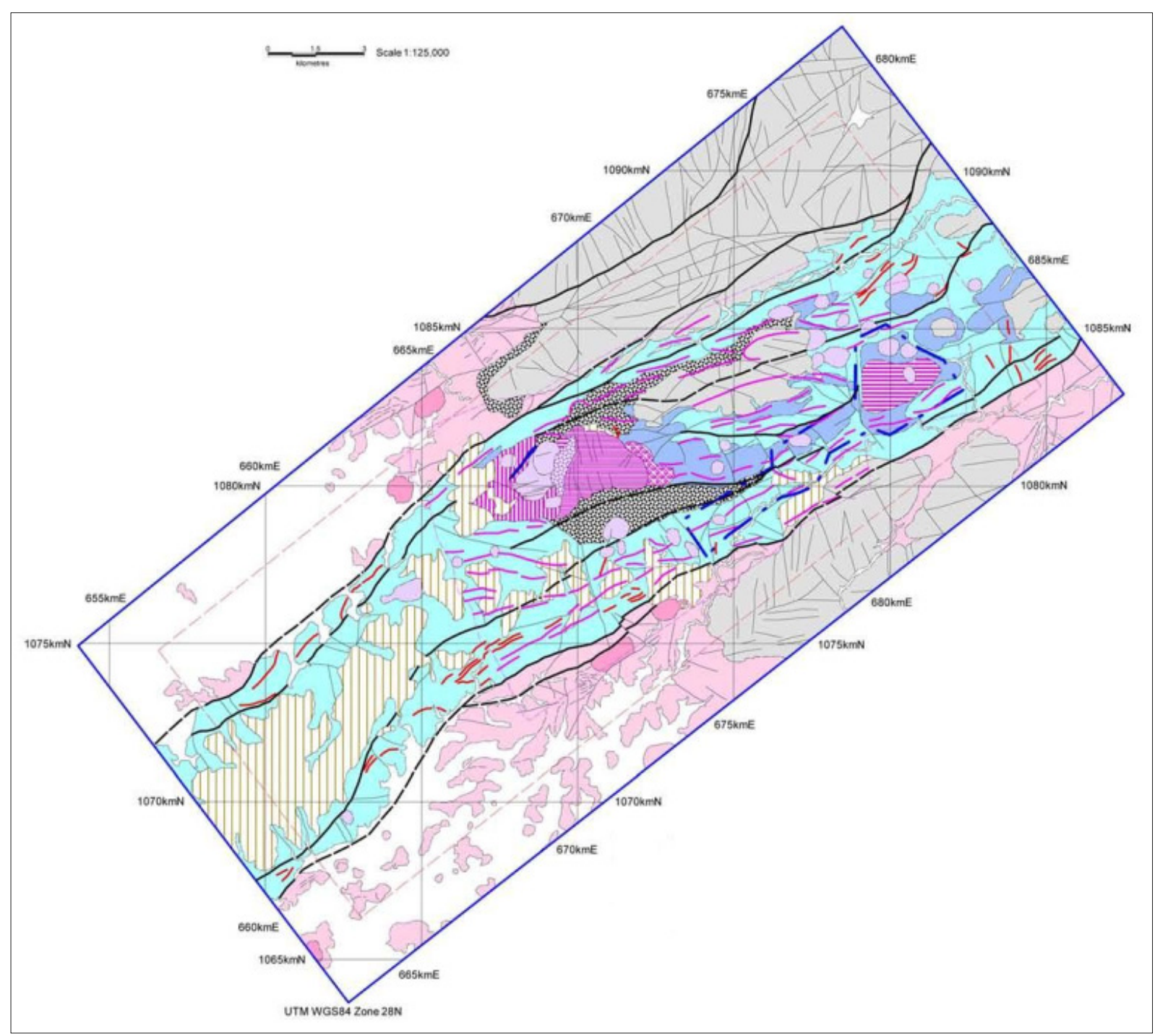

\section{Legend}

\begin{tabular}{|c|c|c|c|}
\hline $\mathbf{Q}$ & Surfacial deposits & slp & Undifferentiated slumped debris and scree \\
\hline $\mathbf{F}$ & Ferricrete & $\mathbf{i}$ & Late mafic or ultrabasic intrusion \\
\hline scr & Scree from Mt. Kakoulima & meh3 & Late Mt. Kakoulima magma chamber cumulates \\
\hline d & Ultrabasic dyke & meh2 & Earlier Mt. Kakoulima magma chamber cumulates \\
\hline $\mathrm{Pz}$ & Early Palaeozoic sandstone & meh1 & First Mt. Kakoulima magma chamber cumulates \\
\hline gr & Archaean granite & mch? & Possible magma chamber cumulates \\
\hline mig & Archaean granite-gneiss, migmatite & ubh & Prominent ultrabasic intrusion \\
\hline & Dyke interpreted from Aster image & ub & Dolerite and ultrabasic intrusions, gneiss screens \\
\hline & Significant fault & & Area of magnetic survey \\
\hline & Other fault or fracture & & Area of concession \\
\hline & Trace of foliation & & \\
\hline
\end{tabular}

Figure 3. Map of Mt Kakoulima showing geological basement (Source: Sable Mining, 2010) 
Geologically, MK belongs to the Kaloum Peninsula and Islands of Loos. The base of the Kaloum Peninsula primarily consists of ultrabasic intrusive rock (dunite). This intrusion in the form of dykes, primary age post (Mesozoic) continued under the Atlantic Ocean, is covered along the coast by marine sedimentary deposits, namely sand, clay and vase, and of altered minerals (produced deterioration-colluviums). The north-eastern end of the solid mass dunite is bordered by the gabbro and norite $(\mathrm{Mz})$ of MK, the granite of the base Precambrian $(\mathrm{Pz})$ and the horizontal sandstones of the Ordovician (Sylla, 1995). MK is a voluminous mafic-ultramafic laccolithic layered intrusion (Diallo et al., 1992). The emplacement of these sills and the laccolith was controlled by old NW-SE lineaments reactivated during Mesozoic time (Bertrand \& Villeneuve, 1989; Deckart et al., 2005).

\section{Geophysical Surveys}

Some geophysical surveys have been done on MK and mineralizations in iron, nickel, copper, cobalt, chrome and PGE have been recognized.

In 1961, a Czechoslovak mission detected concentrations of nickel in its oxidized form near the surface. The study area included three mountains with respective altitudes of $1011 \mathrm{~m}, 946 \mathrm{~m}$ and $878 \mathrm{~m}$. An anomaly was detected by geophysical surveying near Kakoulima train station, which had a depression of $2.6 \mathrm{~km}^{2}$. Geophysical survey of the anomaly was not pushed beyond $20 \mathrm{~m}$, although the thickness of the nickeliferous rocks exceeds 24 m. Mineralized surface fields: $2.6 \mathrm{~km}^{2}$; ore tonnage: $38,816,000$ tonnes; Nickel content: $0.7-0.9 \%$; Nickel reserves: 185,000 tonnes (Brinckmann et al., 2008). Over the period 1979-1981, the Geosurvey International Society (US) conducted a mineral exploration campaign in the country and the geophysical methods used included airborne and ground magnetics, spectrometry and electromagnetics. Thus, this Geosurvey work had put in evidence that the mafic and ultramafic rocks of MK have one of the most important fields of minerals in Guinea, which supported the enriched minerals such as: copper, nickel, cobalt and PGE (CPG, 1983).

MK was explored by SEMAFO from 1996 to 1998 and by Rio Tinto from 1999 to 2001, with both companies focusing on narrow high grade Ni-Cu-Co-PGE intersections in an upper gabbro/pyroxenite horizon. This resulted in the delineation of an average $0.8 \mathrm{~m}$ thick massive sulphide horizon of axial dimensions $100 \mathrm{~m} \times 100$ $\mathrm{m}$ with weighted average grades of $2.78 \% \mathrm{Ni}$ and $0.86 \% \mathrm{Cu}$. To the south of $\mathrm{MK}$ lie extensive laterites overlying mafic-ultramafic cumulates. Nine short vertical holes were drilled in the past by Semafo in a nickeliferous/chromiferous lateritic zone in two areas. All holes mention the omnipresence of $\mathrm{Cr}$ with enriched zones of $+2 \% \mathrm{Cr}$ in many instances. One hole intersected a horizon from $11.5 \mathrm{~m}$ to $26.3 \mathrm{~m}$ containing $3.28 \% \mathrm{Cr}$, $0.58 \% \mathrm{Ni}$ and $0.13 \% \mathrm{Co}$. The $\mathrm{Ni} / \mathrm{Cr}$ laterite mineralization appears usually to relate to a magnetic anomaly which extends along the southern flank of MK. The zone is a few hundred meters in width (Sable Mining, 2010).

In 2004, Mega Uranium Ltd. drilled a total of 9303.5 meters on 23 diamond drill holes in three phases of exploration, comprising 16 holes testing the northern contact zone and 7 in the southern area. Drilling findings included 14.7 meters $0.35 \% \mathrm{Ni}, 0.39 \% \mathrm{Cu}, 0.17 \mathrm{~g} / \mathrm{t} \mathrm{Pt}$ and $0.79 \mathrm{~g} / \mathrm{t} \mathrm{Pd}$, and maximum values over one meter intervals of $0.45 \% \mathrm{Ni}$ and $0.47 \% \mathrm{Cu}$ (Mega Uranium Ltd., 2006).

In 2010, Sable Mining had a majority interest in a new $298 \mathrm{~km}^{2}$ areas on MK, which was a prospective for $\mathrm{Fe}, \mathrm{Ni}$, $\mathrm{Co}, \mathrm{Cr}$, and PGE. Surface sampling and shallow pitting over the general area of the concession had confirmed the geochemistry of the laterite demonstrated in previous investigations. Furthermore, studies also demonstrated why the laterites were exploited for iron in the environs in the 1950s, with many of the results from that program showing $+40 \%$ of iron (Sable Mining, 2010). Sable Mining goal was to study mineral accumulations in the overlying laterite and saprolite horizons.

Past studies thus far have been mainly focused on the south-east flank of MK intrusive, also concentrating on an area of highly anomalous magnetics extending approximately $13 \mathrm{~km}$ in a northeasterly direction. This contains a zone freshly identified by Sable Mining's reinterpretation (both satellite imagery and existing geophysical data) as a further mafic-ultramafic intrusive known as Kakoulima-2. A reconnaissance drilling program with a $160 \mathrm{~mm}$ auger was used to drill 50 holes covering over the $20 \mathrm{~km}^{2}$ area. A further 17 holes were planned to complete that initial program. All analyses were undertaken by ALS Global's ISO certified laboratory in Brisbane, Australia (Sable Mining, 2011). Initial results from the Kakoulima-2 are tabulated below. 
Table 1. Kakoulima-2 results with significant intersection

\begin{tabular}{|c|c|c|c|c|c|c|c|}
\hline Hole & $\begin{array}{l}\text { Hole depth } \\
\qquad(\mathrm{m})\end{array}$ & $\begin{array}{c}\text { Iron Intercept } \\
\text { Grade (m) }\end{array}$ & $\% \mathrm{Fe}^{1}$ & $\begin{array}{c}\text { Chromite Intercept } \\
\text { Grade (m) }\end{array}$ & $\% \mathrm{Cr}_{2} \mathrm{O}_{3}{ }^{2}$ & $\begin{array}{l}\text { Nickel Intercept } \\
\text { Grade (m) }\end{array}$ & $\% \mathrm{Ni}^{3}$ \\
\hline Kak11-50 & 20 & 20 & 38.8 & & & & \\
\hline Kak11-48 & 17 & & & 4 & 2.92 & & \\
\hline Kak11-33 & 16 & 13 & 36.7 & & & & \\
\hline Kak11-32 & 13 & 13 & 46.9 & & & & \\
\hline Kak11-31 & 10 & 10 & 43.2 & 10 & 4.20 & & \\
\hline Kak11-30 & 29 & 29 & 45.1 & 29 & 4.14 & 12 & 0.63 \\
\hline Kak11-29 & 17 & 17 & 43.0 & 17 & 3.93 & 4 & 0.57 \\
\hline
\end{tabular}

${ }^{1}$ Generally, samples with Fe content greater than $30 \%$ are regarded are superior.

${ }^{2}$ Generally, samples with $\mathrm{Cr}_{2} \mathrm{O}_{3}$ content greater than $2.4 \%$ are regarded as superior.

${ }^{3}$ Generally, samples with Ni content greater than $0.5 \%$ are regarded as superior.

Source: Sable Mining, 2011

A mineralogical study by ALS, including QEMSCAN, was initiated to characterize mineralization in different lateritic layers, as a first step to scoping a metallurgical process to produce saleable products. Hand-panning of the lower saprolitic clays, where anomalous magnetic susceptibility was observed, has shown significant quantities of magnetite and chromite in panned concentrates. It was then assumed that the magnetite is a secondary product of the decomposition of the underlying dunite (olivinite) ultramafic rock. In the lateritic sequence above the saprolite, the magnetite altered to hematite, goethite and maghemite (Sable Mining, 2011).

\section{Methods}

\subsection{Literature Review}

Data collection took the form of both literature review and field observations. The literature review was primarily aimed at collecting data on geological basement and all geophysical surveys of MK. Documentation included maps, photographs and organization reports. Newspapers also gave insight into the history of activities on the peak. Books, papers and articles mentioning Mt. Kakoulima were also consulted as well as any relevant scholarly works or research dealing with mafic-ultramafic rock formations.

\subsection{Materials}

During the field observations, a number of important tools were required for data collection:

- An Estwing brand rock hammer was used to gather data on the composition of rock at MK, as well as to determine the nature, strength and history of the rocks. This allowed the researcher to easily split the rocks and expose a fresh surface for analysis.

- The researchers also used maps and photographs to understand the topography and geological basement of MK. (The topographical map was scaled to 1:25,000).

- A geological compass was used together with the above mentioned maps in order to measure the orientation and geometry of the geological structure.

- A loupe with 10x magnification was used to observe details in the rock composition.

- A geological field book was essential for recording observations in the field.

\subsection{Field Work}

In geosciences, field work is considered fundamental to investigating the development of geological formations over time. As Rudwick (1996) asserts, geology is a science in which fieldwork is a central element of practice, not least because so many important geological features are not mobile. It demands integration and study of content knowledge, observation, theories and analyses as well as experimentation which should form the basis for a coherent and consistent interpretation of the location. Field work was therefore critical to this research as observations of the structure, composition and nature of MK, provided the primary data needed to explain its geological formation and lithology. 
Observations of the intrusive mafic-ultramafic formations on MK were taken by a team of researchers during several excursions between March and May, 2010.

\section{Results and Discussion}

\subsection{Structure of Mount Kakoulima}

Being the nearest large mountain to the capital Conakry, the MK is one of the most exceptional rock formations in West Africa. Field research proved that on the crest of MK, is a remarkable image on the rock appearance; an enormous outline of a dog's head which the locals dub as smoking dog (in French 'le chien qui fume') although it is not as impressive as it seems to be. The MK represents a stratified laccolite in Figure 4 (also confirmed by Diallo et al., 1992), which intersects older granitic and metamorphic rocks, covered by Paleozoic sedimentary deposits. At the base of MK, granite and dunite appear to be in direct contact.

From a geomorphological perspective, the slopes of MK form a terrace as shown in Figure 5 below. This terrace reflects the layering structure of the internal mass (stratigraphy), which is related to the different rock types that are encountered in horizontal layers.

From the base to top, field survey exposed the following formation: peridotite (dunite), pyroxenite and gabbro-norite, this is illustrated below in Figure 6. Also, geophysical surveys have proven that MK is stratified mafic and ultramafic rocks, encountered by sulphide mineralization within pyroxenite and gabbro horizon. The average thicknesses of rocks are: peridotite (dunite): $100 \mathrm{~m}$; pyroxenite: $150 \mathrm{~m}$; and gabbro-norite upper $250 \mathrm{~m}$.

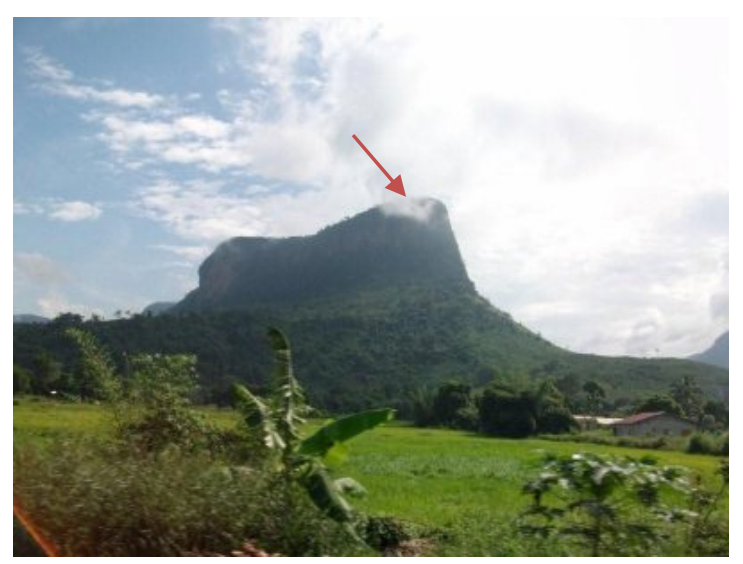

Figure 4. Showing a laccolite form Source: http://www.mmah.e-monsite.com

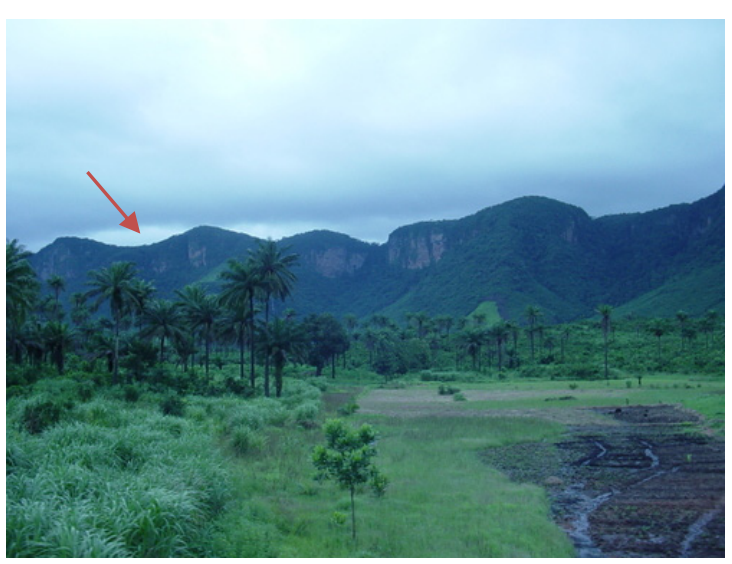

Figure 5. Showing slopes forming a terrace Source: http://www.mmah.e-monsite.com

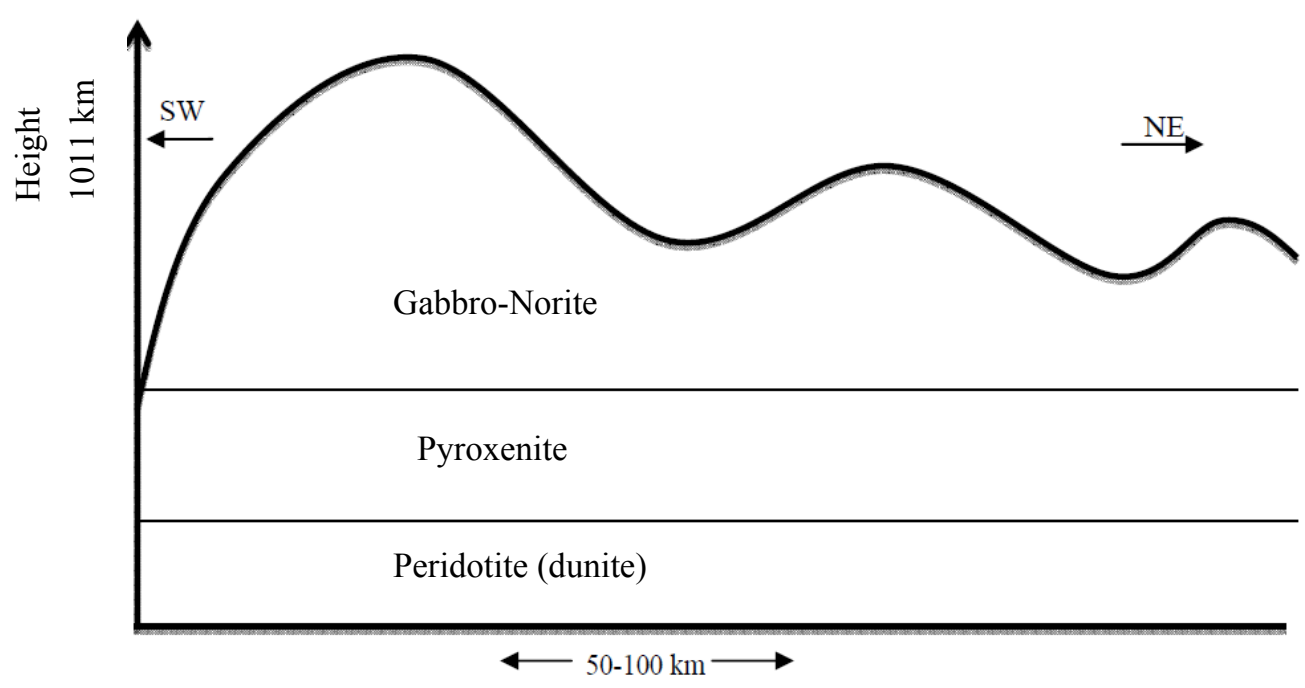

Figure 6. Illustration of the form and structure of Mt Kakoulima 
MK from a structural point of view, is possibly analogue when comparing researches done on the Great Dyke in Zimbabwe (Wilson, 1982; Wilson, 1992; Wilson, 1996; Wilson et al., 2000), the Bushveld Igneous Complex in South Africa (Von et al., 1985; Mitchell,1990; Kruger, 1990; Ealesaand \& Cawthornb, 1996), the Stillwater Igneous Complex in Montana (Bow et al., 1982; Raedeke \& Mccallum, 1984; McCallum, 1996), and the Munni Munni Complex in Australia (Barnes \& Hoatson, 1994). Each of these intrusions is a kind of assemblage of magmatic sediments forming stratified layers where sediment is represented by mineral grains from a gravitational fall in the magma. Cumulus minerals (Plagioclase, orthopyroxene, clinopyroxene, olivine) form the backbone of these rocks and the enveloping cement. In other words, these rock cumuli are accumulations of crystals deposited after a more or less prolonged gravitational fall.

The cumulus phase is dominated by the processes of crystal fractionation. The accumulation of minerals decommitted as a result of the crystallization process occurring in the magma chamber due to a high density of crystals. The accumulated rocks generally exhibit well developed textural stratification. After the cumulus phase, subsequent formation of rocks can happen by crystallization of new mineral fusion (intercumulus) and compaction of the cumulus pile. This phase, which includes overgrowth, develops strong compositional zoning. Crystallization partially forms overgrowth on the primary cumulus crystals, and discrete intercumulus minerals. Compaction occurs in response to the increasing pressure acting on the individual crystals. This leads to a rotation of cumulus crystals, local pressure dissolution (resorption), and a filter pressing of the intercumulus liquid.

These phenomena are called crystalline assemblage of structured mineral stages of MK, which are characterized by a bottom to top succession of ultramafic to mafic rocks: peridotite (dunite), pyroxenite, and gabbro-norite.

\subsection{Process of Formation of Solid}

Field research proved that the dunite (almost olives) lies at the base of the massif. It is an ultramafic rock containing less than $45 \% \mathrm{SiO}_{2}$ formed by early crystallizing and accumulation of grains of olivine and pyroxene by injection of magma during the $1^{\text {st }}$ intrusive phase (see Figure 7). It is also the source of chromite, iron, nickel and cobalt, which is also confirmed by geophysical surveys (see Table 1). On the outcrops of dunite, one can observe large crystals of diallage with the naked eye. The quantity grows in an identical way from bottom to top on the entire thickness of the rock.

The relationships of the dunite with pyroxenite are very complex. These relationships are clearly visible in outcrops under Creek Bridge at the $46.2 \mathrm{~km}$ mark along the former Conakry-Kankan railway. Here, dunite with average grains is intersected by a superimposed pyroxenite dyke with fine grains. A little higher along the bed of the same creek, dunite is substituted by this same pyroxenite. Pyroxenite is also an ultramafic rock, composed basically of minerals of the pyroxene. It is formed by accumulation and compaction of pyroxene crystals by injection of magma during the $2^{\text {nd }}$ intrusive phase (see Figure 7). It is also source of chromite cumulates.

In the Kitima river bed, one can observe a pyroxenite injection in the form of dykes in dunite with bitownite. Thus, these observations demonstrate the existence of a relationship break between the first layer of dunite and pyroxenite of the second layer. On the Kitima river bank, not far from the place where dunite is intersected by pyroxenite, the gabbro-norite injections in the form of dykes in gabbro-norite melanocrat are observable. Gabbro-norite is a mafic rock $\left(45-52 \% \mathrm{SiO}_{2}\right)$ which is often associated with iron, titanium and platinum mineralizations. It is formed as cumulates mafic intrusion by injection of magma during the $3^{\text {rd }}$ intrusive phase (see Figure 7). 


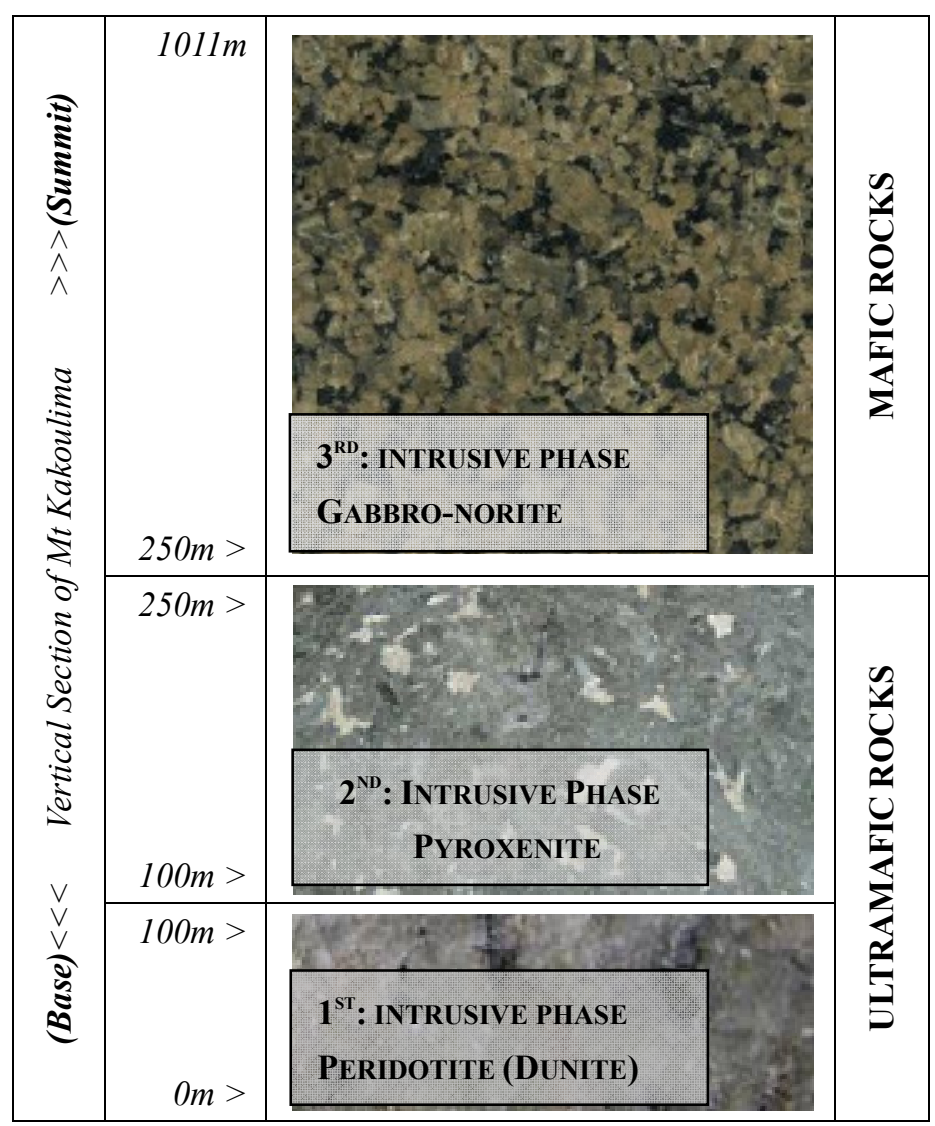

Figure 7. Stratigraphic section of Mt. Kakoulima showing process of formation

In general, the mafic and ultramafic rocks of MK, one can affirm what follows; the solid mass was formed from the result of some injections of magma, i.e. in some intrusive phases. Differentiation took place in-depth in accordance with the following; the ultramafic rocks to the mafic rocks, i.e. dunite to gabbro-norite. The injection of each new portion is passed over magmatic layers already consolidated. From the base to the summit, the massif was formed in three intrusive phases: $1^{\text {st: }}$ peridotite (dunite); $2^{\text {nd }}:$ pyroxenite, $3^{\text {rd: }}$ gabbro-norite; as illustrated in Figure 7 above. These intrusions of magma have caused the formation of MK which contains mining wealth (iron, nickel, copper, cobalt, chrome and PGE).

\section{Conclusion and Recommendations}

This approach overview and analysis have given a general result in order to understand the structure and formational process on MK. Through the investigation presented in this paper, it emerges that the intrusive complex of MK is a solid laminate, formed with the result of some magma injections in some intrusive phases with a Lithological from peridotite (dunite) to pyroxenite to extensive gabbro. Mafic and ultramafic rock, such as MK is usually associated with economically important metal. Magmatic deposits containing exploitable quantities of nickel, copper, chrome and platinum group elements (PGE) are associated with variable quantities of localized sulphide concentrations.

As mentioned in the introduction, limited data have been published on MK. Andrew Grows of Sable Mining notes that 'MK represents a significant underexploited mafic-ultramafic igneous complex which has demonstrated prospectively for nickel, copper, chromite'. In this manner, we recommend scientific methods in the fields of geology, geochemistry, geophysics and economics, etc., to thoroughly and investigate the commercial value of minerals at Mt. Kakoulima, thus enabling the relevant authorities to exploit this formation.

\section{Acknowledgements}

The authors thank anonymous reviewers for their useful comments and suggestions to improve this paper. 


\section{References}

Abouchami, W., Boher, M., Michard, A., \& Albarede, F., (1990). A major 2.1 Ga event of mafic magmatism in West Africa: an early stage of crustal accretion. J. Geophys. Res., 95B, 17605-17629. http://dx.doi.org/10.1029/JB095iB11p17605

Arndt, N. T., \& Goldstein, S. L. (1989). An open boundary between lower continental crust and mantle: its role in crust formation and crustal recycling. Tectonophysics, 161(3-4), 201-212. http://dx.doi.org/10.1016/0040-1951(89)90154-6

Barnes, S. J., \& Hoatson, D. M. (1994). The Munni Munni Complex, Western Australia: Stratigraphy, Structure and Petrogenesis. Journal of Petrology, 35(3), 715-751. http://dx.doi.org/10.1093/petrology/35.3.715

Bertrand, H., \& Villeneuve, M. (1989). Témoins de l'ouverture de l'atlantique central au début du jurassique: les dolerites tholeiitiques continentales de Guinée (Afrique de l'Ouest). C. R. Acad. Sci., Paris 308 (série II), 93-98.

Boher, M., Abouchami, W., Michard, A., Albarede, F., \& Arndt, N. T. (1992). Crustal growth in West Africa at 2.1 Ga. J. Geophys. Res., 97, 345-369. http://dx.doi.org/10.1029/91JB01640

Bow, C., Wolfgram, D., Turner, A., S., Barnes, E. J., Zdepski, M., \& Boudreau, A. (1982). Investigations of the Howland Reef of the Stillwater Complex, Minneapolis Adit area; stratigraphy, structure, and mineralization. Economic Geology, 77(6), 1481-1492. http://dx.doi.org/10.2113/gsecongeo.77.6.1481

Brinckmann et al. (2008). Mines et developpement durable en République de Guinée, gtz Conakry

Cawthorn, R. G., \& Lewis, D. A. (2009). Origin of Anorthosite and Magnetitite Layers in the Bushveld Complex, Constrained by Major Element Compositions of Plagioclase. J. Petrology, 50(9), 1607-1637. http://dx.doi.org/10.1093/petrology/egp042

Cawthorn, R. G., \& McKenna, N. (2006). The extension of the western limb, Bushveld Complex (South Africa), at Cullinan Diamond Mine. Mineralogical Magazine, 70(3), 241-256. http://dx.doi.org/10.1180/0026461067030328

CPG. (1983). Métaux de base et autres substances minérales utiles, Edition de la Commission Culturelle du Comité central du Parti démocratique de Guinée, Imprimerie P. Lumumba. Conakry. p. 85.

Dean, M. H. (2002). Archean Layered Mafic-Ultramafic Intrusions in the West Pilbara Craton, Western Australia: A Synthesis of Some of the Oldest Orthomagmatic Mineralizing Systems in the World. Economic Geology, 97(4), 847-872. http://dx.doi.org/10.2113/gsecongeo.97.4.847

Deckart, K., Bertrand, H., \& Liégeois, J. P. (2005). Geochemistry and Sr, Nd, Pb isotopic composition of the Central Atlantic Magmatic Province (CAMP) in Guyana and Guinea. Lithos, 81, 289-314. http://dx.doi.org/10.1016/j.lithos.2004.09.023

Deckart, K., Féraud, G., \& Bertrand, H. (1997). Age of Jurassic continental tholeiites of French Guyana, Surinam and Guinea: implications for the initial opening of the Central Atlantic Ocean. Earth and Planetary Science Letters, 150, 205-220. http://dx.doi.org/10.1016/S0012-821X(97)00102-7

Diallo et al. (2011). Les enjeux de la gouvernance du secteur minier en Guinée, gtz Conakry

Ealesa, H. V., \& Cawthornb, R. G. (1996). The Bushveld Complex. Developments in Petrology, 15, 181-229. http://dx.doi.org/10.1016/S0167-2894(96)80008-X

Eckstrand, O. R., \& Hulbert, L. J. (2007). Magmatic nickel-copper-platinum group element deposits, in Good fellow, W.D., ed., Mineral Deposits of Canada: A Synthesis of Major Deposit Types, District Metallogeny, the Evolution of Geological Provinces, and Exploration Methods: Geological Association of Canada, Mineral Deposits Division, Special Publication No. 5, 205-222.

Eckstrand, O. R., Good, D. J., Yakubchuk, A., \& Gall, Q. (2004), World distribution of Ni, Cu, PGE, and Cr deposits and camps: Geological Survey of Canada, unpublished update of Open File 3791a.

Ennih, N., \& Liégeois, J. P. (2008). The boundaries of the West African craton, with a special reference to the basement of the Moroccan metacratonic Anti-Atlas belt. Geological Society, London, Special Publications, 297, 1-17.

Ferrsrio, A., \& Garuti, G. (1990). Platinum-Group Mineral Inclusions in Chromitites of the Finero Mafic-Ultramafic Complex (Ivrea-Zone, Italy). Mineralogy and Petrology, 41(2-4), 125-143. http://dx.doi.org/10.1007/BF01168491 
Garuti, G., Fershtater, G., Bea, F., \& Montero, P. (1997). Platinum-group elements as petrological indicators in mafic-ultramafic complexes of the central and southern Urals: preliminary results. Tectonophysics, 276(1-4), 181-194. http://dx.doi.org/10.1016/S0040-1951(97)00050-4

Gebauer, D. (1996). High-pressure ultramafic/mafic rock-association and its felsic country-rocks based on SHRIMP-dating of magmatic and metamorphic zircon domains. Geophysical Monograph Series, 95, 307-329. http://dx.doi.org/10.1029/GM095p0307

Gebauer, D., \& Bernard, J. (1981). U-Pb Zircon and Monazite Dating of a Mafic-Ultramafic Complex and Its Country Rocks. Contrib Mineral Petrol, 76, 292-300. http://dx.doi.org/10.1007/BF00375456

Hurley, P. M., Leo, G. W., White, R. H., \& Fairbairn, H. W. (1971). Liberian age province (about 2700 m.y.) and adjacent provinces in Liberia and Sierra Leone. Geol. Soc. Amer. Bull., 82, 3483-3490. http://dx.doi.org/10.1130/0016-7606(1971)82[3483:LAPAMA]2.0.CO;2

Kruger, F. J. (1990). The stratigraphy of the Bushveld Complex: a reappraisal and the relocation of the Main zone boundaries. South African journal of geology, 93(2), 376-381.

Liégeois, J. P., Black, R., Navez, J., \& Latouche, L. (1994). Early and late Pan-African orogenies (Tuareg shield, Niger). Precambrian Res., 67, 59-88. http://dx.doi.org/10.1016/0301-9268(94)90005-1

Liégeois, J. P., Claessens, W., Camara, D., \& Klerkx, J. (1991). Short lived Eburian orogeny in southern Mali. Geology, tectonics, $\mathrm{U}-\mathrm{Pb}$ and $\mathrm{Rb}-\mathrm{Sr}$ geochronology. Precambrian Res., 50, 111-136. http://dx.doi.org/10.1016/0301-9268(91)90050-K

Marketwire News Releases. (2006). http://markets.hpcwire.com/about/news/read?GUID=614992

McCallum, I. S. (1996). The Stillwater Complex. Developments in Petrology, 15, 441-483. http://dx.doi.org/10.1016/S0167-2894(96)80015-7

Mega Uranium Ltd. (2004). http://www.megauranium.com/news_room/2004/index.php?\&content_id=61

Mega Uranium Ltd. (2006). http://www.megauranium.com/news_room/2006/index.php?\&content_id=192

Mitchell, A. A. (1990). The stratigraphy, petrography and mineralogy of the main zone of the northwestern Bushveld Complex. South African Journal of Geology, 93, 818-831.

Moores, E. M. (1973). Geotectonic significance of ultramafic rocks, Earth-Science Reviews, 9(3), 241-258. http://dx.doi.org/10.1016/0012-8252(73)90093-7

Naldrett, A. J. (1989). Stratiform PGE deposits in layered intrusions. Reviews in Economic Geology, 4, 135-165.

Nasrrddine, Y., Richard, E., Ulf, S., Hervé, B., Miguel, D., Hind, E. H., ... Khalid, R. C. (2011). Large igneous provinces of the West African Craton: The record preserved in regional dyke swarms. LIP of the Month.

Nomade, S., Knight, K. B., Beutel, E., Renne, P. R., Vérati, C., Féraud, G., ... Bertrand, H. (2007). Chronology of the Central Atlantic Magmatic Province: implications for the Central Atlantic rifting processes and the Triassic-Jurassic biotic crisis. Palaeogeography, Palaeoclimatology, Palaeoecology, 244(1-4), 326-344. http://dx.doi.org/10.1016/j.palaeo.2006.06.034

Okano, O., Sato, T., \& Kagami, H. (2000). Rb-Sr and Sm-Nd isotopic studies of mafic igneous rocks from the Ryoke plutono-metamorphic belt in the Setouchi area, Southwest Japan: implications for the genesis and thermal history. Island Arc, 9(1), 21-36. http://dx.doi.org/10.1046/j.1440-1738.2000.00258.x

Pirajno, F., Mao, J., Zhang, Z., Zhang, Z., \& Chai, F. (2008). The association of mafic-ultramafic intrusions and A-type magmatism in the Tian Shan and Altay orogens, NW China: Implications for geodynamic evolution and potential for the discovery of new ore deposits. Journal of Asian Earth, 32(2-4), 165-183. http://dx.doi.org/10.1016/j.jseaes.2007.10.012

Puchtel, I. S., Brügmann, G. E., \& Hofmann, A. W. (1999). Precise Re-Os mineral isochron and Pb-Nd-Os isotope systematics of a mafic-ultramafic sill in the $2.0 \mathrm{Ga}$ Onega plateau (Baltic Shield). Earth and planetary science, 170(4), 447-461.

Quadt, A. (1992). U-Pb zirc on and Sm-Nd geochronology of mafic and ultramafic rocks from the central partof the Tauern Window (eastern Alps). Contrib Mineral Petrol, 110(1), 57-67. http://dx.doi.org/10.1007/BF00310882

Raedeke, L. D., \& Mccallum, I. S. (1984). Investigations in the Stillwater Complex: Part II. Petrology and Petrogenesis of the Ultramafic Series. J. Petrology, 25(2), 395-420. http://dx.doi.org/10.1093/petrology/25.2.395 
Rudwick, M. (1996). Geological Travel and Theoretical Innovation: The Role of Liminal Experience. Social Studies of Science, 26(1), 143-159. http://dx.doi.org/10.1177/030631296026001007

Sable Mining. (2010). Report and accounts, Sable mining Africa LTD, pp. 40-42.

Sable Mining. (2011). Kakoulima Project Update28-Nov-2011 Number 8454S07. Retrieved from http://www.4-traders.com/SABLE-MINING-AFRICA-LD-4008756/news/Sable-Mining-Africa-Ld-Kakouli ma-Project-Update-13909426/

Schoenberg, R., Nägler, Th. F., Gnos, E., Kramers, J. D., \& Kamber, B. S. (2003). The Source of the Great Dyke, Zimbabwe, and Its Tectonic Significance: Evidence from Re - Os Isotopes. The Journal of Geology, 111(5), 565-578. http://dx.doi.org/10.1086/376766

Sun, S. S., Wallace, D. A., Hoatson, D. M., \& Glikson, A. Y. (1991). Use of geochemistry as a guide to platinum group element potential of mafic-ultramafic rocks: examples from the west Pilbara Block and Halls Creek Mobile Zone, Western Australia. Precambrian, 50(1-2), 1-35. http://dx.doi.org/10.1016/0301-9268(91)90045-C

Sylla, M. (1995). Evaluation qualitative de l'état des eaux souterraines de Conakry, en vue de l'alimentation améliorée en eau souterraine des populations, Thèse de mémoire, Centre Géoscientifique Ottawa-Carleton et Université d'Ottawa, p.11.

Von, G. G., Martin, R. S., \& Christopher, J. H. (1985). The Bushveld Complex: Introduction and Review. Economic Geology, 80(4), 803-812. http://dx.doi.org/10.2113/gsecongeo.80.4.803

Wilson, A. H. (1982). The Geology of the Great 'Dyke', Zimbabwe: The Ultramafic Rocks. J. Petrology, 23(2), 240-292. http://dx.doi.org/10.1093/petrology/23.2.240

Wilson, A. H. (1992). The Geology of the Great Dyke, Zimbabwe: Crystallization, Layering, and Cumulate Formation in the P1 Pyroxenite of Cyclic Unit 1 of the Darwendale Subchamber. J. Petrology, 33(3), 611-663. http://dx.doi.org/10.1093/petrology/33.3.611

Wilson, A. H. (1996). The Great Dyke of Zimbabwe. Developments in Petrology, 15, 365-402. http://dx.doi.org/10.1016/S0167-2894(96)80013-3

Wilson, A. H., Murahwi, C. Z., \& Coghill, B. (2000). Stratigraphy, geochemistry and platinum group element mineralisation of the central zone of the Selukwe Subchamber of the GreatDyke, Zimbabwe. Journal of African Earth Sciences, 30(4), 833-853. http://dx.doi.org/10.1016/S0899-5362(00)00055-5 